University of Nebraska - Lincoln

DigitalCommons@University of Nebraska - Lincoln

Faculty Papers and Publications in Animal

Science

Animal Science Department

1980

\title{
Influence of Lactobacillus Acidophilus Inoculum on Gnotobiotic and Conventional Pigs
}

\author{
D. S. Pollmann \\ University of Nebraska-Lincoln \\ D. M. Danielson \\ University of Nebraska-Lincoln \\ W. B. Wren \\ University of Nebraska-Lincoln \\ E. R. Peo, Jr. \\ University of Nebraska-Lincoln \\ K. M. Shahani \\ University of Nebraska-Lincoln
}

Follow this and additional works at: https://digitalcommons.unl.edu/animalscifacpub

Part of the Animal Sciences Commons

Pollmann, D. S.; Danielson, D. M.; Wren, W. B.; Peo, Jr., E. R.; and Shahani, K. M., "Influence of Lactobacillus Acidophilus Inoculum on Gnotobiotic and Conventional Pigs" (1980). Faculty Papers and Publications in Animal Science. 651.

https://digitalcommons.unl.edu/animalscifacpub/651

This Article is brought to you for free and open access by the Animal Science Department at DigitalCommons@University of Nebraska - Lincoln. It has been accepted for inclusion in Faculty Papers and Publications in Animal Science by an authorized administrator of DigitalCommons@University of Nebraska - Lincoln. 


\title{
INFLUENCE OF LACTOBACILLUS ACIDOPHILUS INOCULUM ON GNOTOBIOTIC AND CONVENTIONAL PIGS ${ }^{1}$
}

\author{
D. S. Pollmann ${ }^{2}$, D. M. Danielson ${ }^{2}$, W. B. Wren ${ }^{3}$, E. R. Peo, Jr. ${ }^{2}$ \\ and K. M. Shahani ${ }^{4}$ \\ University of Nebraska ${ }^{5}$, Lincoln 68583
}

\begin{abstract}
Summary
Two trials were conducted to determine the effect of $L$. acidopbilus (bacteria commonly found in probiotics) inoculum on gnotobiotic and conventional pigs. The localization and population levels of $L$. acidopbilus (LA) in the gastrointestinal (GI) tract of 24 gnotobiotic pigs (12 treated and 12 control) were determined by microbiological techniques. Each of the treated pigs received a $10-\mathrm{ml}$ inoculum $\left(2 \times 10^{11}\right.$ viable cells $\left./ \mathrm{ml}\right)$ of acidophilus culture (strain DDS 1) isolated from milk. The control pigs received a sterile deionized water inoculum. The inocula $(10 \mathrm{ml})$ were given in milk daily for 3 days starting when the pigs were approximately 5 days old. At 3, 5, 7 and 9 days postinoculation, pigs were killed, and tissues were removed from seven locations in the GI tract. A 1-g sample of tissue and ingesta (contents) was homogenized and diluted for plate counts on MRS Agar. The treated group had higher LA populations $(P<.001)$ than did the controls. The LA population remained relatively constant over the four periods for the treated group. The colonization did not appear to influence serum metabolites but did increase white blood cell counts $(P<.06)$. In the treated group, the large intestine (cecum and colon) had higher LA populations $(\mathrm{P}<.001)$ than the stomach (cardiac and fundic regions) and small intestine (duodenum, jejunum and ileum). Fecal samples were cultured for determination of the correlation between fecal and tissue
\end{abstract}

\footnotetext{
${ }^{1}$ Published as paper no. 5875, Journal Ser., Ne braska Agr. Exp. Sta.

${ }^{2}$ Dept. of Anim. Sci.

${ }^{3}$ Dept. of Vet. Sci.

${ }^{4}$ Dept. of Food Sci. and Technol.

${ }^{5}$ Acknowledgement is made to Debbie Koester and Alice Teter for their assistance in preparation of the manuscript.
}

lactobacillus populations. The correlation coefficients were not significant, suggesting that fecal flora count is a poor indicator of GI flora. A second trial was conducted to determine the effects of LA inoculum on growth, E. coli and lactobacillus counts, hematology and serum protein levels in nursing, naturally farrowed pigs. When the pigs were 2 days of age, all litters (two control and two treated) were inoculated daily with either the LA culture $(10 \mathrm{ml} / \mathrm{day})$ or sterile water via stomach tubes for 3 days. The pigs were killed and the tissues excised and processed in the same way as in the trial with the gnotobiotic pigs. As the pigs grew older, lactobacillus populations increased linearly $(\mathrm{P}<.05)$ and $E$. coli populations decreased linearly $(\mathrm{P}<.01)$, regardless of treatment. The LA inoculum significantly increased the lactobacillus and coliform populations of the cardiac (nonglandular) region of the stomach. As with the gnotobiotic pigs, correlation coefficients between fecal and tissue flora were not significant for either lactobacilli or coliforms. Average daily gain was slightly $(\mathrm{P}<.10)$ reduced by the LA inoculum, and a slightly higher $(\mathrm{P}<.10)$ white blood cell count was observed for the conventional pigs.

(Key Words: Gnotobiotic Pigs, Probiotics, L. acidopbilus, Colonization, Intestinal Flora.)

\section{Introduction}

In the establishment and maintenance of microbial populations in the digestive tract, some form of adhesion between the organism and the tissue wall is necessary. This association is commonly called colonization or implantation. It has been theorized (Parker, 1975) that for probiotics to be beneficial, colonization must occur.

Fuller and Brooker (1974) and Tortuero (1973) observed that lactobacillus colonization 629 
TABLE 1. INFLUENCE OF ACIDOPHILUS CULTURE ON POPULATION AND LOCATION OF L. ACIDOPHILUS IN GNOTOBIOTIC PIGS ${ }^{\mathrm{a}}$

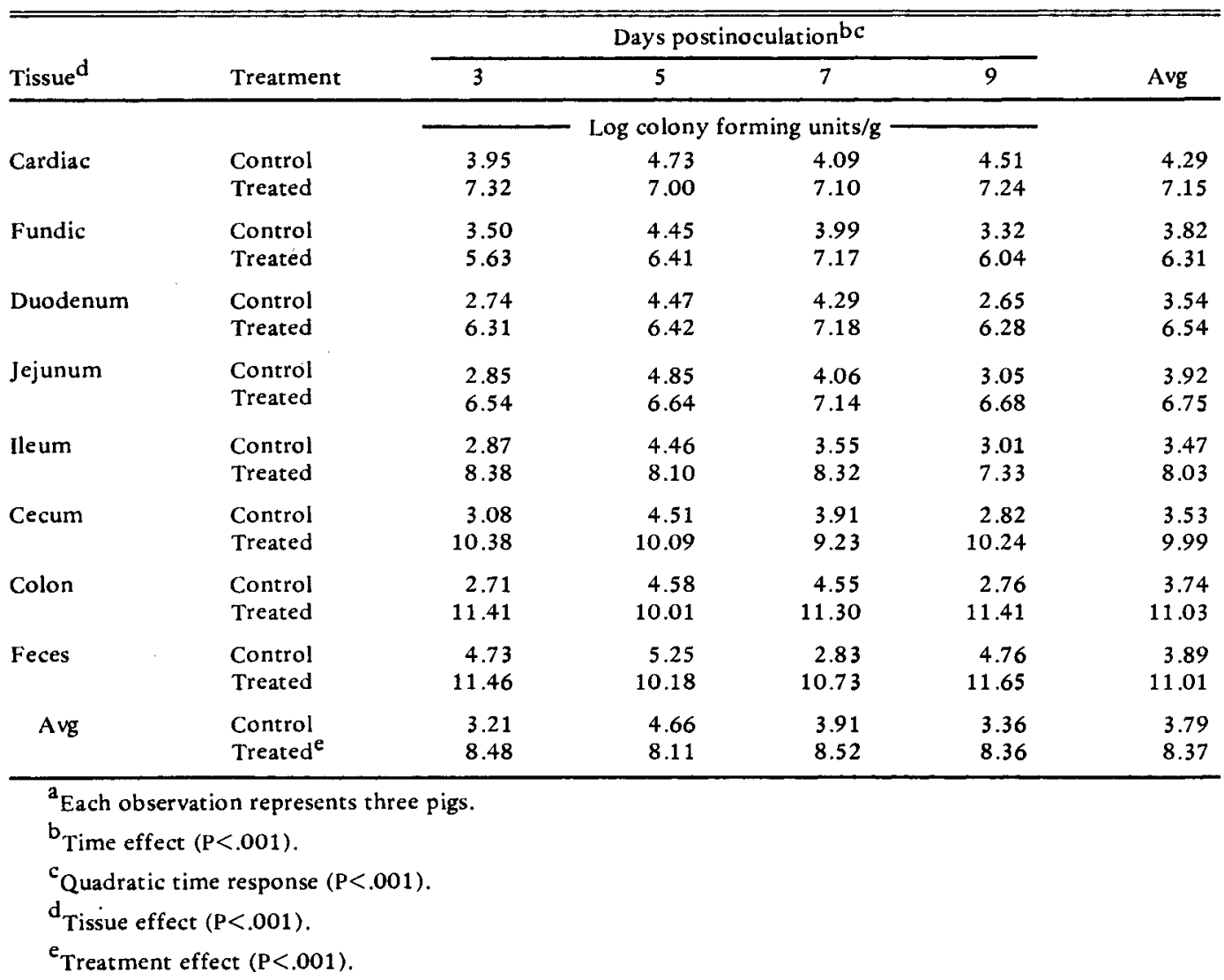

improved gains and feed efficiency. Morotomi et al. (1975) and Savage (1972), using germfree rats, observed that lactobacilli were effective in suppressing other bacterial species. They noted that lactobacillus colonization occurred in the nonglandular portion of the stomach. Muralidhara et al. (1977) showed that L. lactis (isolated from human intestinal contents, concentrated and frozen) suppressed E. coli and suggested that lactobacillus colonization occurred in conventional pigs.

The objective of this study was to determine the effect of $L$. acidopbilus inoculum on gnotobiotic and conventional pigs.

\section{Experimental Procedure}

In the first trial, gnotobiotic pigs were used

\footnotetext{
York.

${ }^{6}$ SPF Lab, Borden Co., 350 Madison Ave., New
}

to determine the extent and location of colonization of $L$. acidopbilus (LA) in the gastrointestinal (GI) tract. The gnotobiotic pigs were derived by the closed hysterotomy (without general anesthesia) method described by Miniats and Jol (1978). After completion of the surgery, eight randomly selected piglets were placed in plastic germ-free isolators. The two isolators were constructed of stainless steel and surmounted with polyvinyl canopies, and were maintained under positive pressure. The isolators were divided into four compartments by removable stainless steel partitions. Each compartment had a wire mesh floor designed to facilitate separation of waste and prevent coprophagy. Air was sterilized by passage through a fiberglass filter and temperature was maintained at $32 \mathrm{C}$ for the entire period. The piglets were fed about $50 \mathrm{ml}$ of a canned milk diet ${ }^{6}$ twice a day starting at about $12 \mathrm{hr}$ after birth; the milk was fed in shallow, sterile, stainless steel troughs. At 5 


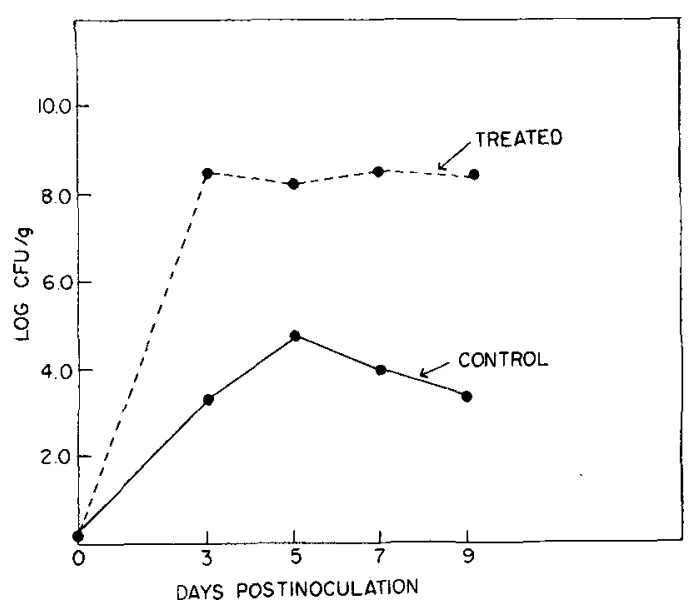

Figure 1. Influence of acidophilus culture on colonization of $L$. Acidophilus in gnotobiotic pigs.

days of age, one group of pigs (individually housed in one isolator) received a $10-\mathrm{ml}^{2}$ inoculum $\left(2 \times 10^{11}\right.$ viable cells $\left./ \mathrm{ml}\right)$ of $\mathrm{LA}$ culture $^{7}$ (strain DDS 1), a frozen concentration that had been isolated from milk. The other four pigs, in the control isolator, received a sterile deionized water inoculum. The inocula were given in the milk once a day for 3 days. To reduce possible contamination of the isolators, the inocula, in capped test tubes, and the canned milk were transferred into the decontamination area and disinfected with $2 \%$ solution of peracetic acid. After $30 \mathrm{~min}$, the containers were transferred from the decontamination area to the isolators.

At 3, 5, 7 and 9 days postinoculation, one pig was removed from each isolator. Approximately $12 \mathrm{hr}$ after feeding, blood samples for cell counts and hematocrit were collected into evacuated glass tubes ${ }^{8}$ that contained sodium fluoride to inhibit glycolysis and EDTA to prevent coagulation. Blood for serum protein and urea analyses were collected into evacuated glass tubes that contained sodium heparin. Cell counts and hematocrits were performed by conventional methods. After centrifugation, the sera were transferred to sterile plastic cul-

\footnotetext{
${ }^{7}$ Acidophilus Culture, Great Lakes Biochemical Co., Milwaukee, WI.

${ }^{8}$ Vacutainer tube, Becton-Dickinson, Rutherford, $\mathrm{NJ}$.

${ }^{9}$ Sigma Technical Bull. No. 630, Sigma Chemical Co., P.O. Box 14508, St. Louis, MO.
}

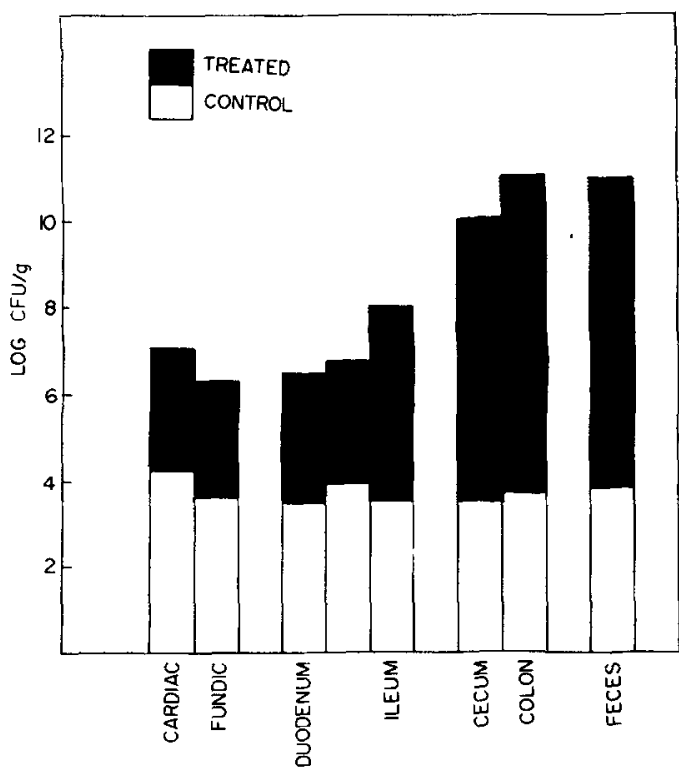

Figure 2. Influence of acidophilus culture on location and population of L. Acidopbilus in gnotobiotic pigs.

ture tubes, sealed and frozen $(-10 \mathrm{C})$ until analyzed. Total serum protein was determined by the Lowry method with Folin-Ciocalteau reagent (Lowry et al., 1951). Serum albumin was determined with a $\mathrm{kit}^{9}$ by a bromcresol green colorimetric determination. Serum globulin was estimated as the difference between total protein and albumin. Urea nitrogen determinations were completed with an automated system as described by Frankel (1970).

After blood sampling, the pigs were killed

\section{TABL.E 2. FECAL-TISSUE CORRELATION COEFFICIENTS FOR GNOTOBIOTIC PIGS THAT RECEIVED $L$. ACIDOPHILUS CULTUREa}

\begin{tabular}{lc}
\hline $\begin{array}{l}\text { Indepen- } \\
\text { dent } \\
\text { variable }\end{array}$ & $\begin{array}{c}\text { Corre- } \\
\text { lation } \\
\text { with } \\
\text { feces }\end{array}$ \\
\hline Cardiac & .29 \\
Fundic & -.37 \\
Duodenum & -.25 \\
Jejunum & -.23 \\
Ileum & .21 \\
Cecum & -.02 \\
Colon & .51 \\
\hline
\end{tabular}

\footnotetext{
${ }^{a}$ Represents partial or residual correlation coefficients.
} 
TABLE 3. INFLUENCE OF L. ACIDOPHILUS INOCULUM ON HEMATOLOGY IN GNOTOBIOTIC PIGS

\begin{tabular}{|c|c|c|c|c|c|c|}
\hline \multirow[b]{2}{*}{ Parameter } & \multirow[b]{2}{*}{ Treatment } & \multicolumn{4}{|c|}{ Days postinoculation } & \multirow[b]{2}{*}{ Avg } \\
\hline & & 3 & 5 & 7 & 9 & \\
\hline Hematocrit, 96 & $\begin{array}{l}\text { Control } \\
\text { Treated }\end{array}$ & $\begin{array}{l}28.5 \\
30.8\end{array}$ & $\begin{array}{l}27.1 \\
31.2\end{array}$ & $\begin{array}{l}34.6 \\
34.8\end{array}$ & $\begin{array}{l}30.6 \\
32.8\end{array}$ & $\begin{array}{l}30.2 \\
32.4\end{array}$ \\
\hline Red blood cells, million $/ \mathrm{mm}^{3}$ & $\begin{array}{l}\text { Control } \\
\text { Treated }\end{array}$ & $\begin{array}{l}5.60 \\
5.06\end{array}$ & $\begin{array}{l}4.75 \\
5.70\end{array}$ & $\begin{array}{l}6.33 \\
6.25\end{array}$ & $\begin{array}{l}5.74 \\
5.99\end{array}$ & $\begin{array}{l}5.60 \\
5.75\end{array}$ \\
\hline White blood cells, thousand $/ \mathrm{mm}^{3}$ & $\begin{array}{l}\text { Control } \\
\text { Treated }\end{array}$ & $\begin{array}{l}4.42 \\
6.40\end{array}$ & $\begin{array}{l}4.67 \\
6.43\end{array}$ & $\begin{array}{l}5.07 \\
5.29\end{array}$ & $\begin{array}{l}4.00 \\
5.93\end{array}$ & $\begin{array}{l}4.64 \\
6.03\end{array}$ \\
\hline
\end{tabular}

${ }^{*} \mathrm{P}<.06$.

by electrocution, and an autopsy was performed to excise samples from seven predetermined locations along the GI tract for microbiological evaluation. The two sites of the stomach were the cardiac (nonglandular) and fundic (glandular) regions. The three sites of the small intestine were the duodenum (150 $\mathrm{mm}$ from the pylorus posterior to bile and pancreatic ducts), the jejunum (1 $\mathrm{m}$ from the pylorus) and the ileum $(300 \mathrm{~mm}$ from ileo. cecal junction). The entire cecum and a portion

\footnotetext{
${ }^{10}$ Polytron, Brinkmann Instruments, Westbury, New York.

${ }^{11}$ Anaerobic gas mixture, Union Carbide Corp., Linde Division, New York.

12 Forma Scientific Anaerobic Incubator (Model 3159), Forma Scientific, Inc., Marietta, OH.
}

of the colon $(100 \mathrm{~mm}$ anterior and posterior to apex) were selected in the large intestine. In addition, a fecal sample was removed from the posterior colon for determination of the correlation between fecal and tissue flora.

A sample (approximately $1 \mathrm{~g}$ ) of tissue and ingesta was placed in $100 \mathrm{ml}$ of sterile phos. phate buffer in a dilution bottle. The samples were homogenized with a Polytron ${ }^{10}$ homogenator. The blade of the homogenator was rinsed twice, and rinse solution was poured into the dilution bottle. The blade of the homogenator was cleaned and flamed between each sample. The samples were diluted in 100fold steps for enumeration of the organisms on pour plates with MRS agar. Duplicate samples were incubated anaerobically with a gas mixture $^{11}\left(10 \% \mathrm{H}_{2}\right.$ and $\left.90 \% \mathrm{CO}_{2}\right)$ in an anaerobic incubator ${ }^{12}$ for $48 \mathrm{hr}$ at $37 \mathrm{C}$. All

TABLE 4. INFLUENCE OF L. ACIDOPHILUS INOCULUM ON BLOOD PROTEIN LEVELS IN GNOTOBIOTIC PIGS

\begin{tabular}{|c|c|c|c|c|c|c|}
\hline \multirow[b]{2}{*}{ Criterion $^{\mathbf{a}}$} & \multirow[b]{2}{*}{ Treatment } & \multicolumn{4}{|c|}{ Days postinoculation } & \multirow[b]{2}{*}{ Avg } \\
\hline & & 3 & 5 & 7 & 9 & \\
\hline Total protein & $\begin{array}{l}\text { Control } \\
\text { Treated }\end{array}$ & $\begin{array}{l}2.91 \\
2.65\end{array}$ & $\begin{array}{l}2.55 \\
2.79\end{array}$ & $\begin{array}{l}2.94 \\
2.58\end{array}$ & $\begin{array}{l}3.13 \\
3.15\end{array}$ & $\begin{array}{l}2.88 \\
2.79\end{array}$ \\
\hline Albumin & $\begin{array}{l}\text { Control } \\
\text { Treated }\end{array}$ & $\begin{array}{r}1.42 \\
.99\end{array}$ & $\begin{array}{l}1.10 \\
1.53\end{array}$ & $\begin{array}{l}1.88 \\
1.77\end{array}$ & $\begin{array}{l}2.23 \\
2.00\end{array}$ & $\begin{array}{l}1.66 \\
1.57\end{array}$ \\
\hline Globulin & $\begin{array}{l}\text { Control } \\
\text { Treated }\end{array}$ & $\begin{array}{l}1.49 \\
1.67\end{array}$ & $\begin{array}{l}1.45 \\
1.25\end{array}$ & $\begin{array}{r}1.06 \\
.80\end{array}$ & $\begin{array}{r}.89 \\
1.14\end{array}$ & $\begin{array}{l}1.22 \\
1.22\end{array}$ \\
\hline A:G ratio & $\begin{array}{l}\text { Control } \\
\text { Treated }\end{array}$ & $\begin{array}{r}1.09 \\
.60\end{array}$ & $\begin{array}{r}.78 \\
1.56\end{array}$ & $\begin{array}{l}2.28 \\
2.52\end{array}$ & $\begin{array}{l}2.36 \\
1.87\end{array}$ & $\begin{array}{l}1.63 \\
1.64\end{array}$ \\
\hline Urea nitrogen & $\begin{array}{l}\text { Control } \\
\text { Treated }\end{array}$ & $\begin{array}{l}21.7 \\
19.2\end{array}$ & $\begin{array}{l}28.7 \\
37.2\end{array}$ & $\begin{array}{r}12.6 \\
8.4\end{array}$ & $\begin{array}{l}16.8 \\
17.1\end{array}$ & $\begin{array}{l}19.9 \\
20.5\end{array}$ \\
\hline
\end{tabular}

\footnotetext{
${ }^{a}$ Values for all criteria are millgrams $/ 100 \mathrm{ml}$.
} 
TABLE 5. INFLUENCE OF L. ACIDOPHILUS INOCULUM ON LACTOBACILLUS COUNTS IN CONVENTIONAL PIGS ${ }^{\mathrm{a}}$

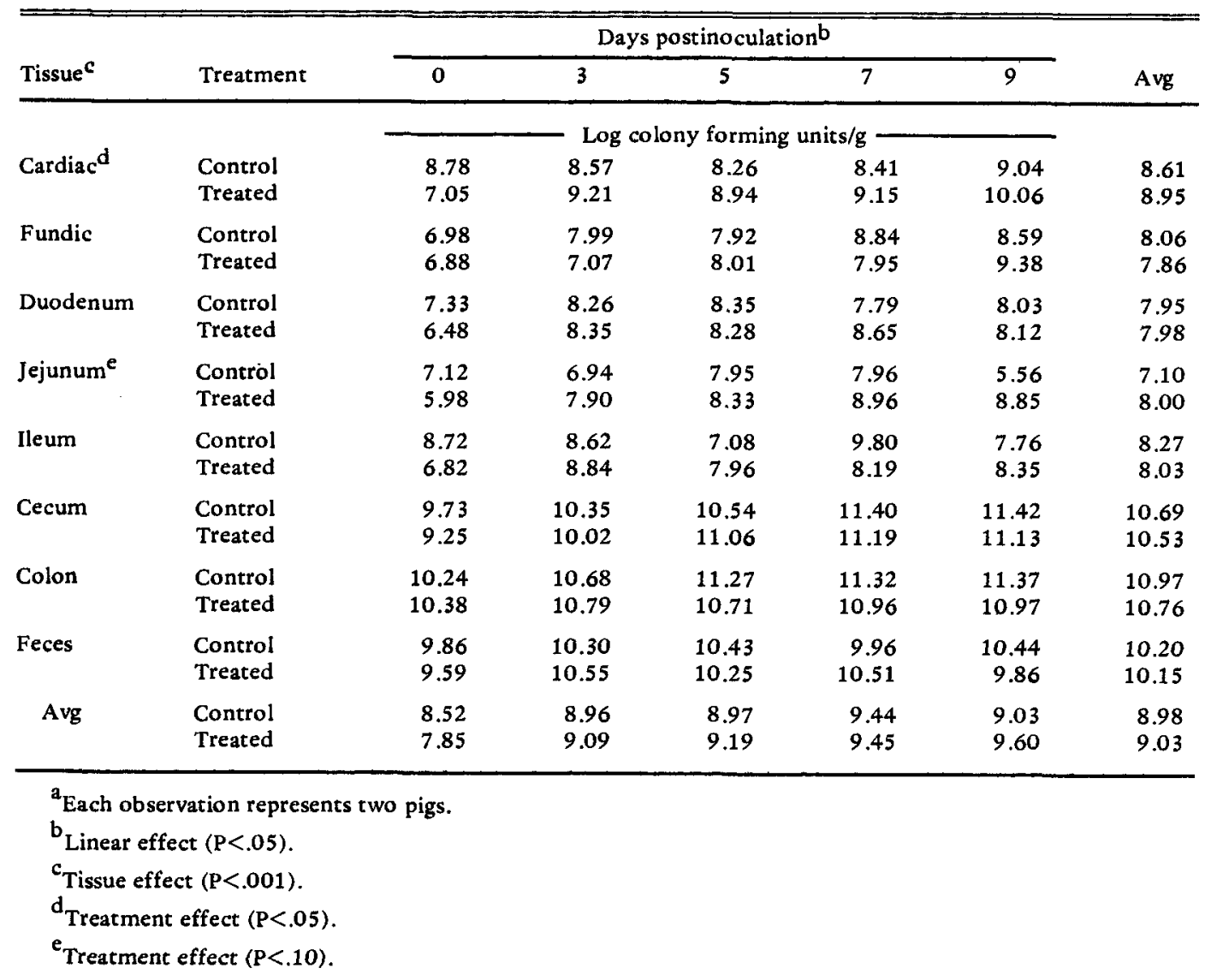

petri dishes that had 30 to 300 colonies were counted.

The experimental procedures were repeated for two more sows, with an additional pig from each litter killed without receiving the canned milk diet.

In the second trial, conventional pigs from four sows (two treated and two control) were placed in an environmentally regulated room with a cement wall divider designed to crosscontamination between the treatment groups. When the pigs reached 2 days of age, each litter was inoculated daily with either the LA culture $(10 \mathrm{ml} / \mathrm{pig} / \mathrm{day})$ or sterile water via stomach tubes for 3 days. All pigs were weighed on the first inoculation date and at the time of sacrifice for determination of average daily

\footnotetext{
${ }^{13}$ Difco Laboratories, Detroit, MI.
}

gains. The procedure used for bleeding, killing and lactobacilli count was the same as that described for the trial with the gnotobiotic pigs. Coliforms were also counted, using violet red bile agar ${ }^{13}$.

Data were analyzed by standard analysis procedures, and correlation coefficients were calculated by procedures and methods of Barr et al. (1976).

\section{Results and Discussion}

Gnotobiotic Pigs. The localization and population levels of $L$. acidopbilus in the gnotobiotic pigs are summarized in table 1 . The treated pigs had higher $(\mathrm{P}<.001)$ LA populations than the controls, and the population remained fairly constant over the four treatment periods for the treated group (figure 1). The control group showed an increase in lactobacilli after receiving the milk diet, but the levels were 
lower than those observed for the treated pigs. Microbiological counts were made on the canned milk product. MRS agar, which is selective for lactobacillus but not specific for $L$. acidophilus, was used. It is possible that contaminates from the milk caused a low level persistence of the organism but were insufficient for colonization. It is believed that the lactobacillus species in the milk may have been a thermophilic organism that is common in canned milk products. A few bulged milk cans were observed.

In the treated group, the large intestine had higher $(\mathrm{P}<.001)$ LA populations than the stomach and small intestine (figure 2 ), whereas in the control group, the populations were similar at all the locations. Since the ingesta were not separated from the tissue, the area of colonization could not be accurately defined. Morotomi et al. (1975) and Savage (1972) have reported that lactobacilli colonize in the keratinized cells of the nonglandular portion of the stomach. The microbial counts in the large intestine may have been confounded with organisms that had been sloughed off the epithelium of the stomach.

Many researchers have used fecal lactobacillus count as an indicator of lactobacillus population in the GI tract. The correlation coefficients between tissue and fecal flora are presented in table 2. From these data, it appears that fecal lactobacillus count is a poor indicator of tissue lactobacillus population.

$L$ acidophilus inoculum did not significantly affect the hematocrit and red blood cell counts

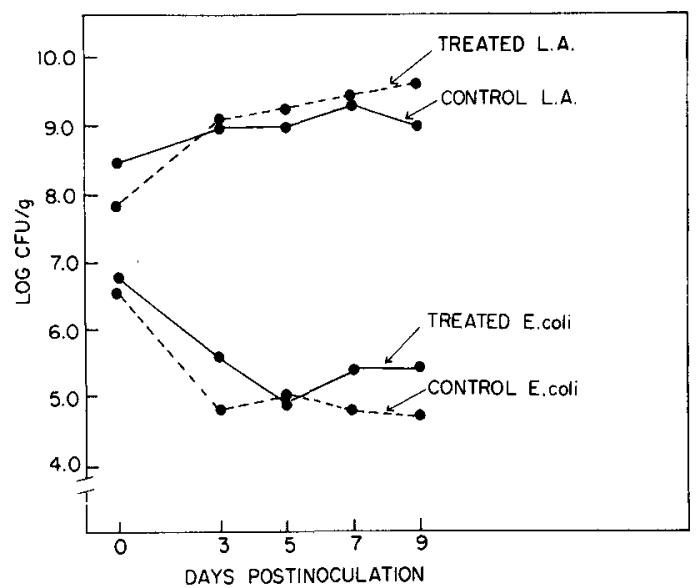

Figure 3. Influence of $L$. Acidopbilus on lactobacillus and coliform counts in conventional pigs.

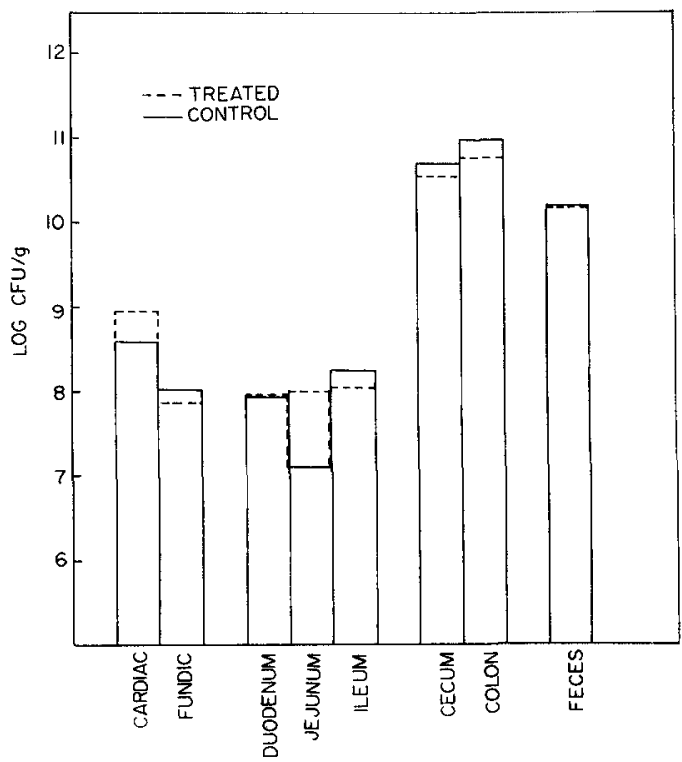

Figure 4. Influence of $L$. Acidopbilus inoculum on location and population of lactobacilli in conventional pigs.

but did increase $(\mathrm{P}<.06)$ white blood cell counts (table 3 ). It is well recognized that normal microbial flora contributes to the defense of the hose. Abrams and Bishop (1965) showed that flora inocula given to germ-free mice increased leukocytic exudation, a process of great defensive importance to the host. Wagner (1959) inoculated monoflora rats with lactobacilli, which resulted in increased antibody formation. Since an increase in leukocytes was observed, lactobacilli may have a role in the immume response. As an additional

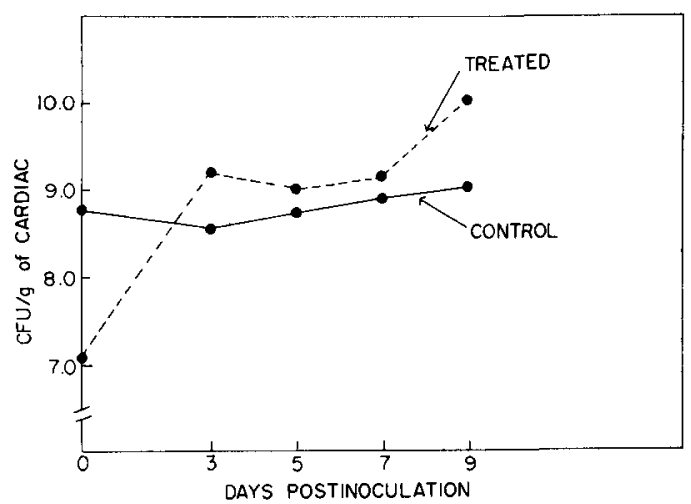

Figure 5. Influence of $L$. Acidopbilus inoculum on lactobacillus populations in the cardiac portion of conventional pigs. 


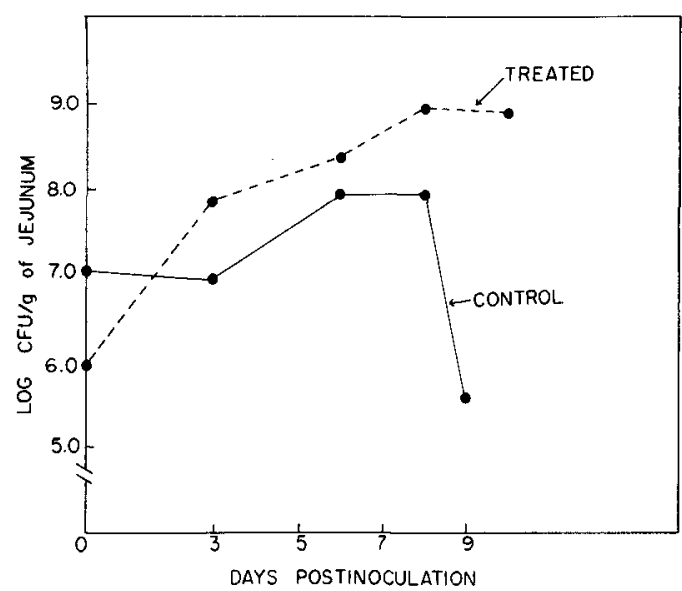

Figure 6. Influence of $L$. Acidophilus inoculum on lactobacillus populations in jejunum of conventional pigs. indicator of the possible role of lactobacilli, serum proteins (albumin and globulin) and urea nitrogen were determined (table 4). The LA inoculum did not significantly affect the serum metabolites.

Conventional Pigs. It is evident from the gnotobiotic work that LA populations were maintained without significant change for up to 9 days postinoculation. These results raise the question of whether LA inoculum would colonize in the conventional pig. The data in table 5 support the contention that LA will, in fact, colonize in the gut of contaminated pigs. As the pigs grew older, lactobacillus populations increased $(\mathrm{P}<.05)$ linearly. $\mathrm{Al}$ though the effect of LA inoculum averaged over the tissue locations was not significant, the $\log$ of colony-forming units was con-

TABLE 6. INFLUENCE OF L. ACIDOPHILUS INOCULUM ON COLIFORM COUNTS IN CONVENTIONAL PIGS ${ }^{\mathrm{a}}$

\begin{tabular}{|c|c|c|c|c|c|c|c|}
\hline \multirow[b]{2}{*}{ Tissue $^{d}$} & \multirow[b]{2}{*}{ Treatment } & \multicolumn{5}{|c|}{ Days postinoculation bc } & \multirow[b]{2}{*}{ Avg } \\
\hline & & 0 & 3 & 5 & 7 & 9 & \\
\hline & & & Log & $y$ form & $\mathrm{ts} / \mathrm{g}$ & & \\
\hline Cardiac $^{e}$ & $\begin{array}{l}\text { Control } \\
\text { Treated }\end{array}$ & $\begin{array}{l}4.09 \\
4.98\end{array}$ & $\begin{array}{l}2.38 \\
4.96\end{array}$ & $\begin{array}{l}3.22 \\
3.81\end{array}$ & $\begin{array}{l}3.30 \\
4.36\end{array}$ & $\begin{array}{l}2.98 \\
4.69\end{array}$ & $\begin{array}{l}3.19 \\
4.56\end{array}$ \\
\hline Fundic & $\begin{array}{l}\text { Control } \\
\text { Treated }\end{array}$ & $\begin{array}{l}3.52 \\
4.72\end{array}$ & $\begin{array}{l}2.95 \\
3.80\end{array}$ & $\begin{array}{l}3.04 \\
3.73\end{array}$ & $\begin{array}{l}2.82 \\
3.58\end{array}$ & $\begin{array}{l}3.22 \\
3.92\end{array}$ & $\begin{array}{l}3.11 \\
3.95\end{array}$ \\
\hline Duodenum & $\begin{array}{l}\text { Control } \\
\text { Treated }\end{array}$ & $\begin{array}{l}5.04 \\
4.15\end{array}$ & $\begin{array}{l}4.53 \\
4.82\end{array}$ & $\begin{array}{l}4.00 \\
3.80\end{array}$ & $\begin{array}{l}3.18 \\
4.37\end{array}$ & $\begin{array}{l}3.53 \\
3.38\end{array}$ & $\begin{array}{l}4.05 \\
4.10\end{array}$ \\
\hline Jejunum & $\begin{array}{l}\text { Control } \\
\text { Treated }\end{array}$ & $\begin{array}{l}4.13 \\
4.79\end{array}$ & $\begin{array}{l}3.27 \\
4.13\end{array}$ & $\begin{array}{l}4.30 \\
4.59\end{array}$ & $\begin{array}{l}4.54 \\
4.61\end{array}$ & $\begin{array}{l}2.78 \\
4.97\end{array}$ & $\begin{array}{l}3.81 \\
4.62\end{array}$ \\
\hline Ileum & $\begin{array}{l}\text { Control } \\
\text { Treated }\end{array}$ & $\begin{array}{l}7.00 \\
6.62\end{array}$ & $\begin{array}{l}5.93 \\
5.64\end{array}$ & $\begin{array}{l}4.35 \\
4.36\end{array}$ & $\begin{array}{l}6.20 \\
4.32\end{array}$ & $\begin{array}{l}5.64 \\
4.40\end{array}$ & $\begin{array}{l}5.82 \\
5.07\end{array}$ \\
\hline Cecum & $\begin{array}{l}\text { Control } \\
\text { Treated }\end{array}$ & $\begin{array}{l}9.52 \\
9.53\end{array}$ & $\begin{array}{l}6.85 \\
7.05\end{array}$ & $\begin{array}{l}6.86 \\
5.92\end{array}$ & $\begin{array}{l}6.35 \\
8.01\end{array}$ & $\begin{array}{l}6.71 \\
6.95\end{array}$ & $\begin{array}{l}7.26 \\
7.49\end{array}$ \\
\hline Colon & $\begin{array}{l}\text { Control } \\
\text { Treated }\end{array}$ & $\begin{array}{l}9.73 \\
9.58\end{array}$ & $\begin{array}{l}5.99 \\
6.52\end{array}$ & $\begin{array}{l}6.86 \\
5.79\end{array}$ & $\begin{array}{l}5.68 \\
6.61\end{array}$ & $\begin{array}{l}6.67 \\
6.86\end{array}$ & $\begin{array}{l}6.99 \\
7.07\end{array}$ \\
\hline Feces & $\begin{array}{l}\text { Control } \\
\text { Treated }\end{array}$ & $\begin{array}{l}9.80 \\
9.77\end{array}$ & $\begin{array}{l}6.58 \\
7.49\end{array}$ & $\begin{array}{l}7.54 \\
7.17\end{array}$ & $\begin{array}{l}6.46 \\
7.25\end{array}$ & $\begin{array}{l}6.29 \\
8.06\end{array}$ & $\begin{array}{l}7.34 \\
7.50\end{array}$ \\
\hline Avg & $\begin{array}{l}\text { Control } \\
\text { Treated }\end{array}$ & $\begin{array}{l}6.60 \\
6.78\end{array}$ & $\begin{array}{l}4.81 \\
5.55\end{array}$ & $\begin{array}{l}5.02 \\
4.90\end{array}$ & $\begin{array}{l}4.82 \\
5.39\end{array}$ & $\begin{array}{l}4.73 \\
5.40\end{array}$ & $\begin{array}{l}5.20 \\
5.60\end{array}$ \\
\hline
\end{tabular}

${ }^{a}$ Each observation represents two pigs.

${ }^{b}$ Linear effect $(P<.01)$.

${ }^{c}$ Quadratic effect $(P<.01)$.

$\mathrm{d}_{\text {Tissue effect }}(\mathrm{P}<.001)$.

$\mathrm{e}_{\text {Treatment effect }}(\mathrm{P}<.05)$. 


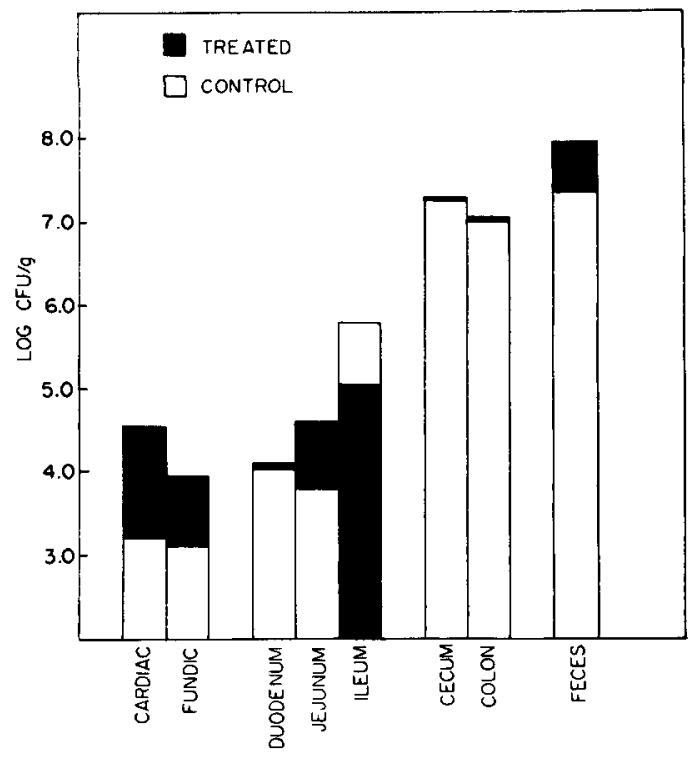

Figure 7. Influence of $L$. Acidophilus inoculum on location and population of coliforms in conventional pigs.

sistently higher for the treated group (figure 3 ). There was a difference $(\mathrm{P}<.001)$ in populations at the various locations along the tract (figure 4). As with the gnotobiotic pigs, the large intestine had the greatest population of lactobacilli. The inoculum significantly increased the lactobacillus populations of the cardiac (nonglandular) region of the stomach (figure 5). These results are in agreement with those reported by several researchers (Savage, 1969, 1971; Kunstyr, 1974; Kunstyr et al., 1976; Morotomi et al., 1975), who observed colonization in the nonglandular region of the stomach in rodents. The lactobacillus populations of the jejunum were also slightly affected $(\mathrm{P}<.10)$ by the inoculum (figure 6$)$.

The effect of LA inoculum on E. coli populations is shown in table 6. As the pigs grew older, a linear and quadratic decrease $(\mathrm{P}<.01)$ in the coliform counts was observed. Several researchers (Muralidhara et al., 1977; Sandine et al., 1972; Mitchell and Kenworthy, 1976) have reported that the administration of lactobacilli suppressed $E$. coli, a normal and abundant bacterial inhabitant of the digestive tract. It has been suggested that $E$. coli are the major cause of scouring in swine (Sandine $e t$ al., 1972). In this study, both lactobacillus and coliform counts were increased $(P<.05)$ in the cardiac region of the stomach (figure 7 ), with
TABLE 7. INFLUENCE OF L. ACIDOPHILUS

INOCULUM ON PARTIAL CORRELATION

COEFFICIENTS OF FECAL COUNTS WITH

TISSUE COUNTS IN CONVENTIONAL PIGS

\begin{tabular}{|c|c|c|}
\hline Organism & $\begin{array}{l}\text { Independent } \\
\text { variable }\end{array}$ & $\begin{array}{l}\text { Corre - } \\
\text { lation } \\
\text { coeffi - } \\
\text { cient } \\
\text { with } \\
\text { feces }^{\text {a }}\end{array}$ \\
\hline Lactobacilli & $\begin{array}{l}\text { Cardiac } \\
\text { Fundic } \\
\text { Duodenum } \\
\text { Jejunum } \\
\text { Ileum } \\
\text { Cecum } \\
\text { Colon }\end{array}$ & $\begin{array}{r}.55 \\
.07 \\
-.14 \\
.15 \\
-.04 \\
.52 \\
.50\end{array}$ \\
\hline Coliforms & $\begin{array}{l}\text { Cardiac } \\
\text { Fundic } \\
\text { Duodenum } \\
\text { Jejunum } \\
\text { Ileum } \\
\text { Cecum } \\
\text { Colon }\end{array}$ & $\begin{array}{r}-.39 \\
-.46 \\
-.22 \\
.12 \\
.47 \\
.60 \\
.25\end{array}$ \\
\hline
\end{tabular}

${ }^{a}$ Residual or partial correlation coefficients.

no evidence of diarrhea.

As with the gnotobiotic pigs, the correlation coefficients between fecal and tissue flora were

TABLE 8. INFLUENCE OF L. ACIDOPHILUS INOCULUM ON AVERAGE DAILY GAIN AND HEMATOLOGY IN CONVENTIONAL PIGS $^{a}$

\begin{tabular}{lcc}
\hline & \multicolumn{2}{c}{ Treatment } \\
\cline { 2 - 3 } \multicolumn{1}{c}{ Item } & Control & Treated \\
\hline ADG, $\mathrm{g}^{\mathrm{b}}$ & 151 & 124 \\
Hematocrit, \%c & 35.7 & 31.4 \\
RBC, million $/ \mathrm{mm}^{3}$ & 5.14 & 4.76 \\
WBC, thousand $/ \mathrm{mm}^{3} \mathrm{~b}$ & 13.3 & 17.6 \\
Nucleated RBC, no./100 WBC & 11.7 & 7.4 \\
Smudge cells, no./100 WBC & 22.3 & 26.4 \\
Differential count, \% & & \\
Neutrophils & 30.1 & 36.6 \\
Bands & 19.2 & 16.4 \\
Lymphocytes & 49.2 & 46.4 \\
Monocytes & .3 & .1 \\
Eosinophils & .7 & .4 \\
Basophils & .2 & .1 \\
\hline
\end{tabular}

${ }^{a}$ Each observation represents 10 pigs.

$\mathrm{b}_{\mathrm{P}<.10}$.

$\mathrm{c}_{\mathrm{P}}<.05$. 
TABLE 9. INFLUENCE OF L. ACIDOPHILUS INOCULUM ON SERUM PROTEINS IN CONVENTIONAL PIGS $^{\mathrm{a}}$

\begin{tabular}{|c|c|c|c|c|c|c|c|}
\hline \multirow[b]{2}{*}{ Item $^{b}$} & \multirow[b]{2}{*}{ Treatment } & \multicolumn{5}{|c|}{ Days postinoculation } & \multirow[b]{2}{*}{ Avg } \\
\hline & & 0 & 3 & 5 & 7 & 9 & \\
\hline \multirow[t]{2}{*}{ Urea nitrogen } & Control & 14.25 & 9.37 & 9.04 & 11.69 & 11.99 & 11.27 \\
\hline & Treated & 34.15 & 16.06 & 15.07 & 13.01 & 13.34 & 18.32 \\
\hline \multirow[t]{2}{*}{ Total protein } & Control & 3.69 & 3.29 & 3.28 & 3.55 & 4.38 & 3.64 \\
\hline & Treated & 3.91 & 4.29 & 3.81 & 4.02 & 3.62 & 3.93 \\
\hline \multirow[t]{2}{*}{ Albumin ${ }^{\mathrm{c}}$} & Control & 1.58 & 2.13 & 2.49 & 2.75 & 3.11 & 2.41 \\
\hline & Treated & 1.58 & 1.89 & 2.28 & 2.68 & 2.79 & 2.24 \\
\hline \multirow[t]{2}{*}{ Globulin ${ }^{\mathrm{cd}}$} & Control & 2.11 & 1.17 & .80 & .80 & 1.27 & 1.23 \\
\hline & Treated & 2.34 & 2.40 & 1.54 & 1.35 & .82 & 1.69 \\
\hline \multirow[t]{2}{*}{$A: G$ ratio $^{d}$} & Control & .75 & 1.96 & 3.14 & 4.36 & 2.46 & 1.96 \\
\hline & Treated & .72 & .79 & 1.33 & 2.01 & 3.77 & 1.33 \\
\hline
\end{tabular}

\footnotetext{
${ }^{a}$ Each observation represents two pigs.

${ }^{b}$ All values listed are milligrams $/ 100 \mathrm{ml}$.

${ }^{c}$ Quadratic effect $(P<.05)$.

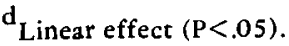

not significant for lactobacilli and coliforms (table 7). Therefore, the validity of fecal flora as an indicator of microbial population of the intestinal tract is questionable.

Average daily gains were slightly reduced $(\mathrm{P}<.10)$ by the lactobacillus inoculum (table 8 ). The LA-inoculated group had a lower $(\mathrm{P}<.10)$ hematocrit with slightly higher white blood cell counts. The other hematological parameters, serum proteins and urea nitrogen (table 9) were not significantly affected by the LA inoculum.

\section{Literature Cited}

Abrams, G. D. and J. E. Bishop. 1965. Normal flora and leukocyte mobilization. Arch. Path. 79:213.

Barr, A. J., J. H. Goodnight, J. P. Sall and J. T. Helwig. 1976. A user's guide to SAS-76. SAS Institute Inc., Raleigh, NC.

Fuller, R. and B. E. Brooker. 1974. Lactobacilli which attach to the crop epithelium of the fowl. Amer. J. Clin. Nutr. 27:1305.

Frankel, S. 1970. Nitrogen. In S. Frankel, S. Reitman and A. C. Sonnerwirth (Ed.) Gradwohl's Clinical Laboratory Methods and Diagnosis (7th Ed.) C. V. Mosby Co., New York.

Kunstyr, 1. 1974. Some quantitative and qualitative aspects of the stomach microflora of the conventional rat and hamster. Zbl. Vet. Med. A $21: 553$

Kunstyr, I., K. Peters and K. Gartner. 1976. Investigations on the function of the rat forestomach. Lab. Anim. Sci. 26:166.

Lowry, O. H., N. J. Rosebrough, A. L. Farr and R. T. Randall. 1951. Protein measurements with folin phenol reagent. J. Biol. Chem. 193:256.

Miniats, O. P. and D. Jol. 1978. Gnotobiotic pigs - derivation and rearing. Can. J. Comp. Med. 42 : 428.

Mitchell, I. De G. and R. Kenworthy. 1976. Investigations on a metabolite from Lactobacillus bulgaricus which neutralizes the effect of enterotoxin from Escherichia coli pathogenic for pigs. J. Appl. Bacteriol. 41:163.

Morotomi, M., T. Watanabe, N. Suegara, Y. Kawai and M. Mutai. 1975. Distribution of indigenous bacteria in the digestive tract of conventional and gnotobiotic rats. Infect. Immun. 11:962.

Muralidhara, K. S., G. G. Sheggeby, P. R. Elliker, D. C. England and W. E. Sandine. 1977. Effect of feed ing lactobacilli on the coliform and lactobacillus flora of intestinal tissue and feces from piglets. J. Food Protection 40:288.

Parker, R. B. 1975. Applications of lactobacillus feeding in swine and other livestock. Amer. Feed Manufacturers Assoc. Nutr. Council, November, p. 38.

Sandine, W. E., K. S. Muralidhara, P. R. Elliker and D. C. England. 1972. Lactic acid bacteria in food and health; a review with special reference to enteropathogenic Escherichia coli as well as certain enteric diseases and their treatment with antibiotics and lactobacilli. J. Milk and Food Technol. 35:691.

Savage, D. C, 1969. Microbial interference between indigenous yeast and lactobacilli in the rodent stomach. J. Bacteriol. 98:1278.

Savage, D. C. 1972. Associations and physiological interactions of indigenous microorganisms and gastrointestinal epithelia. Amer. J. Clin. Nutr. 24:1372.

Tortuero, F. 1973. Influence of the implantation of Lactobacillus acidopbilus in chicks on growth, feed conversion, malabsorption of fat syndrome and intestinal flora. Poul. Sci. 52:197.

Wagner, M. 1959. Serologic aspects of germ-free life. Ann. NY Acad. Sci. 78:261. 